\title{
Transfer of Hungarians from Slovakia in Czechoslovak Politics before Paris Peace Conference 1946 Štefan ŠUTAJ
}

\author{
Společenskovedný ústav Slovenskej akadémie vied \\ Institute of Social Sciences of the Slovak Academy of Sciences \\ Karpatská 5, 04001 Košice, Slovakia \\ sutaj@saske.sk
}

The representatives of Czechoslovak politics tried to solve the problem of minorities in future Czechoslovakia during and after the war already, so that future generations would not have to solve minority problems leading to war conflicts. They worked on the assumption that national minorities had caused the disintegration of Czechoslovakia. The London exile, represented by Edvard Beneš, saw priority in solving the German issue, but they contemplated also the position of the Hungarian minority in Slovakia. In the Study Institute of London, they prepared analytical materials for the needs of the Foreign Ministry and of the President. One of them, the material called Transfer of Minority Population from the Č.S.R., sent on 30 June 1943 by Sergej Ingr, Minister of National Defence, to President Edvard Beneš, ${ }^{1}$ was based on the assumption that it was in the interest of Czechoslovakia to ensure that the frontier zone was inhabited by state-loyal population, and it submitted four possible solutions of how to meet that strategic plan. A - displace minority population without compensation and with consent of the Allies; ${ }^{2}$ B - cede a specific territory with minority population and in specific proportion to such population; after that, displace other part of minority population; ${ }^{3} \mathrm{C}$ - exchange minority population from the ČSR for a part of population of "Czechoslovak" nation from Germany and Hungary ${ }_{i}^{4}$ D - forcible displacement of minority population from the ČSR in the period of "so called controlled

\footnotetext{
1 Archiv Ústavu T. G. Masaryka (Archive of T. G. Masaryk Institute in Prague, hereinafter referred only as AÚTGM), f. Edvard Beneš II., card file 147, Transfer.

2 Displacement of 450 thousand Hungarians from whole districts of Slovakia and Carpathian Ruthenia was expected, particularly in the frontier area, or in a specific percentage from every district, or possibly specification of a quota for the number of inhabitants of German and Hungarian nationality. The procedure was determined for German population and was to be applied also on the situation of Slovakia and Carpathian Ruthenia. Slovakia was to be divided into four areas for the needs of the transfer; the transfer was to be controlled from Bratislava and it was to take about three months, with 15 transports per day. (f. 5055-5063) The project assumed also displacement of Polish population.

3 That alternative did not deal specifically the solution options concerning territorial changes in Slovakia.

4 For Hungary, the project considered 346,053 Slovaks from Hungary - including 104,819 who had claimed allegiance to Slovak nationality in the 1930 census and 241,234 "Slovak speaking Hungarian citizens" who were expected to register for displacement particularly in case of opportunity to acquire property. In Czechoslovakia, including Carpathian Ruthenia, 681,460 Hungarians were assumed; therefore the Czechoslovak authorities were to strive to achieve an exchange in proportion of 1:1,5 (1:10 for Germans, respectively), and so 163,000 Hungarians would stay in Czechoslovakia after the exchange.
} 


\begin{tabular}{c|cr|c}
\hline 64 & $\begin{array}{c}\text { ARTICLES } \\
\text { Štefan ŠUTAJ }\end{array}$ & $\begin{array}{c}\text { Transfer of Hungarians from Slovakia in Gzechoslovak } \\
\text { Politics hefore Paris Peace Conference } 1946\end{array}$ & \\
\hline
\end{tabular}

revolution". ${ }^{5}$ The four alternatives had a common denominator. They were to lead to Czechoslovakia without national minorities, and one of the means consisted in relocation of foreign language population.

The Proposal for Solution of the Minority Issue in the ČSR (Interim memorandum) was another material containing the foundations of future minority policy, prepared in 1944 at the Study Department of the Foreign Ministry of Beneš' administration in London. Jaroslav Císař, its author, characterized the results of Versailles minority policy in Central Europe. He stated that the Versailles system had failed in three areas. It had not protected the minorities in "notoriously violent states (Germany and Italy); it was not able to assert itself in the states that had theoretically taken over its commitments, but practically were determined to violate it knowingly, constantly and cynically (Hungary and Poland), becoming a disaster to states that observed or tried to observe the assumed minority commitments". ${ }^{6}$ The author stated that it was necessary to find a new solution for the minority issue. The issue could be solved "neither by preserving the minority protection nor by its withdrawal", and therefore there was only one possibility left, i.e. to solve it by "removal of the minorities." Contrary to the preceding document, this document stated that national minorities could not be removed by territorial changes, as it was known that "the problem had resulted from the impossibility of finding a borderline that would not leave a minority on one or another side". A modification of the border in favour of Germany (Hungary) would lead to an "absurd result" of territorial strengthening of the defeated country. The project considered forced assimilation a non-democratic measure, stating also that relocation of a whole minority could not be achieved based on voluntariness and brings also negative consequences with it (,it is inhuman and, in this regard, takes over the ideology and methods of Nazism against which the war was waged"); established a dangerous precedent also for other than ethnic minorities; was technically unmanageable in case of large number of persons; did not distinguish between guilty and innocent persons; was unjust towards offenders from among own nation; would lead to departure of great amount of qualified labour; the necessary homogeneity would not be achieved without ban on free movement. However, despite such assessment, the resulting evaluation considered the displacement of population an inevitable step to ensure peace.

The memorandum defined the following main principles of solution: the members of the German and Hungarian minorities who had been accepted as citizens of enemy states would be deprived of the citizenship; those who had offended against the Czechoslovak state would be forced to leave; the others would be allowed to stay if they manifested

5 In case of that alternative, it was expected that immediately upon restoration of the Czechoslovak border from 1937, foreign language population from a range of about $50 \mathrm{~km}$ from the border would be displaced on foot and the remaining population by motor vehicles. The displaced persons would be allowed to take with them only things they were able to carry. The displacement of 550 thousand Hungarians in the first displacement stage and 21 thousand in the second was expected. The first stage was to take place within seven days; four pontoon bridges over the Danube were to be built, and a part was to be transported by "steamboat ferries". The second stage was to take place with the help of trains, within other seven days. A list of the property left behind would be made, to become part of the reparations.

6 AÚTGM, f. Edvard Beneš II., card file 147, Proposal for Solution of the Minority Issue in the ČSR (Interim memorandum). Proposal from 26 April 1944.

7 Ibidem 
willingness to assimilate into the nation "on whose territory they lived"; the obligation to take over citizens of German and Hungarian minority had to be governed by international conventions. $^{8}$

The Slovak political circles in emigration also admitted radical solutions in relation to Hungarians in Slovakia during war already. The message from 10 March 1943, sent by Viliam Radakovič to London, stated that Hungary was hated in Slovakia and that measures were discussed to destruct its political influence, even at the cost of relocation of the Hungarians from Central Europe beyond the Ural Mountains. Only the most radical solutions were discussed in minority issues. "The Germans will be displaced, if not something worse, and the Hungarians will be displaced or exchanged for Slovaks from Hungary and Austria." ${ }^{9}$ The official Czechoslovak requirements in relation to future peace treaties with Germany and Hungary were formulated in London exile in a special Aide-memoire from 24 August 1944, submitted to the European Consultative Commission. They concerned Germany but should be applied also towards Hungary. Its fourth part (Transfer Germans/Magyars) outlined the need of displacement of population of German (Hungarian) nation. Even though the presence of the Hungarian minority in the ČSR was considered a less dangerous problem, the government reserved the right to proceed against the Hungarians in similar way as against the Germans. ${ }^{10}$ In late 1944, the concept of the London Czechoslovak representation was based on equal approach to Germany and Hungary, substantiating it, as was stated also in the note from 14 November 1944, handed over to the Soviet envoy of the Czechoslovak government in London, V. Z. Lebedev, by the fact that the difference between the policy of Germany and Hungary had consisted only in the size of the country and in the influence on the development of Europe. It conveyed the interest of Czechoslovakia, as a country adjacent to Hungary and a country that had been attacked by Hungary, in taking part in determination of the conditions to be imposed to the enemy Hungary. ${ }^{11}$ The memorandum of the Czechoslovak Foreign Ministry from 23 November 1944, sent to the representatives of the Soviet Union, Great Britain and the USA, ${ }^{12}$ contained an analysis of national concepts assessed from different perspectives. - The Czechoslovak government reserved the right to proceed against the Hungarian minority in similar way as against the German minority - the Memorandum was based on the assumption that a transfer need not be necessarily implemented in an inhuman manner.

The effort to displace the Hungarian population from Czechoslovakia has become part of the Czechoslovak plans for solution of minority issues and it expressed itself in international debates about the Armistice Agreement with Hungary. On 30 December 1944, Hubert

8 Ibidem

9 Národní archiv (National Archive, Prague, hereinafter referred only as NA), f. London Archive, card file 25. Radakovičs message from Slovakia for E. Beneš from 10 March 1943.

10 Archiv Ministerstva zahraničních věcí (Archive of the Foreign Ministry, Prague, hereinafter referred only as AMZV), f. London Archive - secret, card file 153. Czechoslovak requirements related to peace treaties with Germany and Hungary, formulated in the special Aide-memoire from 24 August 1944.

11 AMZV, f. London Archive - secret, card file 153. The note stored in secret files of the London Archive in AMZV ČR is mentioned by LANTAYOVÁ-ČIERNA, Dagmar: Tradícia a dejiny. Vybrané kapitoly zo slovensko-madarských a slovensko-ruských vztáahov (1934-1949), Bratislava 2009, 17.

12 LANTAYOVÁ-ČIERNA, Dagmar: Podoby česko-slovensko-mad’arského vzt́ahu 1938-1949, Bratislava 1992, 56-57. 


\begin{tabular}{c|cc|c}
\hline 66 & $\begin{array}{c}\text { ARTIClES } \\
\text { Štefan ŠUtaJ }\end{array}$ & $\begin{array}{r}\text { Transfer of Hungarians from Slovakia in Gzechoslovak } \\
\text { Politics before Paris Peace Conference 1946 }\end{array}$ & \\
\hline
\end{tabular}

Ripka, the Secretary of State at the Foreign Ministry in London, when holding talks with Soviet diplomats, Fedor Tarasevitch Gusev, the USSR ambassador to Great Britain, and Ivan Andreyevitch, the legation advisor of the USSR embassy at allied governments, conveyed the Czechoslovak requirements: 1) the Hungarian army should leave the territory it had occupied in 1938 and in March 1939; 2) Hungary should renounce the Viennese Arbitration and the action from March 1939, it should recognize them as violent actions and acknowledge the integrity of the pre-Munich Czechoslovak border; 3) the principle of transfer and population exchange should be integrated into the armistice conditions; 4) Hungary should acknowledge that the state of war with Czechoslovakia had begun on 7 October 1938 (in compliance with Litvinov's definition of "aggressor" from 1933); 5) that Hungary should commit itself to redress the damages it had caused to Czechoslovakia. $\mathrm{He}$ asked them to convey the requirements to the Soviet government, referring to the memorandum prepared by the Czechoslovak government with regard to the conditions of armistice with Germany and Hungary. H. Ripka substantiated the approach to the Hungarians as an important precedent for displacement of the Sudeten Germans. ${ }^{13}$ Gusev suggested at that point already that the transfer issues could be difficultly integrated into the Armistice Agreement. ${ }^{14}$ Zdeněk Fierlinger, the Czechoslovak ambassador to Moscow, passed the Czechoslovak memorandum on armistice with Hungary also to William Averell Harriman, the American ambassador. Harriman believed that the idea of transfer could be difficultly formulated in the Armistice Agreement and that it should be considered in peace talks. ${ }^{15} \mathrm{H}$. Ripka substantiated the Czechoslovak initiatives for integration of the transfer into the Armistice Agreement by arguing that after the war, both voluntary and involuntary movement of population would take place and that it was expected that the population would drive off (",expel“) the Germans and Hungarians from the state. Therefore it would be more favourable to create organizational preconditions for such movement and to oblige the Hungarians to accept such persons to their territory. ${ }^{16}$ Before the text of the Armistice Agreement was submitted by the Hungarian representative, Fierlinger was invited to talks by Deputy Foreign Minister Vladimir Georghievitch Dekanozov, after the talks with Valerian Alexandrovich Zorin, future ambassador to Czechoslovakia. Fierlinger emphasized three requirements to Dekanozov at the meeting. Transfer was the first concern. He suggested that Hungary should have to accept former Czechoslovak citizens of Hungarian nationality, considering them its citizens with all consequences ${ }^{17}$ Before the armistice talks, Fierlinger had tried to win over also Yugoslavian representatives to support Czechoslovakia. He met Sinish Shimich, the Yugoslavian representative, who informed him that Yugoslavia had no objections against the draft Armistice Agreement, but that in his opinion, transfer did not

13 AMZV, f. London Archive - secret, card file 153. H. Ripka's information from 1 January 1945 for the embassy in Moscow. See: LANTAYOVÁ-ČIERNA, 2009, 12, 22-23, 80.

14 AMZV, f. London Archive - secret, card file 153. Dispatch No. 146/45 from 5 January 1945.

15 AMZV, f. London Archive - secret, card file 153. Dispatch No. 311/45 from 9 January 1945.

16 AMZV, f. London Archive - secret, card file 153. Dispatch No. 285/45 from 12 January 1945.

17 AMZV, f. London Archive - secret, card file 153. Dispatch No. 632/45 from 16 January 1945. The second issue concerned the status of war between Czechoslovakia and Hungary. He proposed either 7 October 1938 as the date when the first act of aggression took place, or the day of the Viennese Arbitration, 2 November 1938 . The third requirement asked for representation in the Allied Inspection Committee to Hungary. 
belong to that agreement but to peace talks, and therefore they would not try to enforce the proposal. At the same time, he confirmed that in the future they could support such proposal, and as for Yugoslavia, "the Yugoslavian government does not intend to restrict its own right to expel unwanted citizens of Hungarian or German nationality now already". ${ }^{18}$ The talks about the Armistice Agreement, held in Moscow on 15 January 1945, were attended by Viacheslav Michailovich Molotov, the Foreign Minister, W. A. Harriman, the USA ambassador, and John Arthur Balfour, the British representative. Zdeněk Fierlinger, the ambassador of the London exile government to Moscow, and S. Simich for Yugoslavia were invited as well. The Hungarian delegation to the talks was led by János Gyöngyösi, Foreign Minister of the interim government, and István Balogh, the Secretary of State. At the talks, Molotov expressed consent to the Czechoslovak requirement for transfer of "Hungarian citizens not liked by the Czechoslovakians". Harriman stated that he was against everything that resembled population exchange, even remotely, and asked for quantification of the number of citizens potentially affected by such measures. Fierlinger argued that they did not know what to do with Hungarian collaborators. "We do not want to shoot or hang them", and "from human perspective", he considered their displacement the most adequate solution. Balfour suggested leaving such issues for the peace talks, arguing that he did not have authorization for them. ${ }^{19}$ In spite of emphasized special thanks to Molotov after the talks, the Czechoslovak representatives were not satisfied with the fact that they had not succeeded in pushing through the idea of exchange or transfer into the Armistice Agreement. In the dispatch from 19 January 1945, H. Ripka asked the Czechoslovak embassy to push through at least the adoption of the principle that the Hungarians had to accept the Czechoslovak Hungarians who would leave or be "expelled" from Czechoslovakia. Ripka emphasized in the talks that the Hungarian issue, if not solved in the Armistice Agreement, would have to be solved during liberation of Slovakia. "But then there is a danger that the Hungarians will protest, if they are not forced to it now." 20 The Czechoslovak transfer requirements were supported just at the talks only by the Soviet Union, but it did not insist on the requirement, in the interest of adoption of a common attitude. ${ }^{21}$ The Moscow talks were completed on 20 January 1945, by signing the Armistice Agreement; on behalf of the three Central Powers, it was signed by Kliment Yephremovich Voroshilov who also became president of the Allied Inspection Committee to Hungary. The principles of the Armistice Agreement with Hungary constituted preconditions in Czechoslovakia for the new concept of steps towards Hungarians on the Slovak territory, based on the ambitions and ideas of the Czechoslovak policy.

For the first period, until the arrival of the Czechoslovak government to Košice in April 1945, the influence of the exile policy on the situation on the Slovak territory was only

18 AMZV, f. London Archive - secret, card file 153. Dispatch No. 544/1945 from 15 January 1945.

19 AMZV, f. London Archive - secret, card file 153. Dispatch No. 738/45 from 17.1.1945. See: LANTAYOVÁ-ČIERNA, 2009, 12.

20 lbidem.

21 For more details on the attitude of the Soviet Union to the Hungarian issues see: BARNOVSKÝ, Michal: Sovietsky zväz, komunisti a riešenie mad’arskej otázky na Slovensku v rokoch 1945-1950, in: Bolševismus, komunismus a radikální socialismus v Československu. Vol. III, KÁRNíK, Zdeněk - KOPEČEK, Michal (eds.), Praha 2004, 154-182. 


\begin{tabular}{c|cc|c}
\hline 68 & $\begin{array}{c}\text { ARTICLES } \\
\text { Štefan ŠUTAJ }\end{array}$ & $\begin{array}{r}\text { Transfer of Hungarians from Slovakia in Gzechoslovak } \\
\text { Politics hefore Paris Peace Conference 1946 }\end{array}$ & \\
\hline
\end{tabular}

platonic. The actual policy was carried out by the Board of Commissioners of the Slovak National Council (SNR) and it was manifested in program documents and decrees. The Slovak political representation did not deal with the concept of future situation of national minorities. The decrees of SNR and political declarations of the communists and democrats from the uprising period and in early 1945 did not mention displacement of the Hungarian minority from the Slovak territory. They included predominantly measures in the area of education, adopted during the uprising, confiscation of enemy lands and displacement of so called "anyáses", resulting from the Armistice Agreement. The other measures had the form of political proclamations (punishment of enemies, population exchange, reSlovakization, employment of population in reconstruction works). ${ }^{22}$

The Czechoslovak nationality policy started acquiring more tangible contours particularly in connection with preparation of the program of the first government of the National Front of Czechs and Slovaks, known as the "Košice Government Programme". The relation to other than Slavic minorities were shaped by opinions of representatives surrounding E. Beneš and the London executive, the Moscow communist exile and consultations with representatives of the Soviet Union. The message sent by Jaromír Smutný to Hubert Ripka about Edvard Beneš' meeting with Molotov in presence of Jan Masaryk, Fierlinger, Vyshinski and Zorin in Moscow on 23 March 1945, mentioned that the President discussed also the issue of border to Germany, Hungary and Poland, the transfer of German and Hungarian population and the determination of a quota for reparations from Hungary to the ČSR. "The President is satisfied with the results of the talks. He considers his talks with the Soviets concluded." 23

Immediately after adoption of the Košice Government Programme, Finance Minister Vavro Šrobár prepared a proposal for displacement of 400 thousand Hungarians from Czechoslovakia. He expected that 70 \% Hungarians would be displaced from every municipality and their property would be confiscated. They would be allowed to take only basic things and food for one week with them. The Hungarian government would have to recompense them for the confiscated property, which would be included in the account of reparations to be paid by Hungary to Czechoslovakia based on the Armistice Agreement. Šrobár's substantiation was based on the thesis that the Hungarians had contributed to destroy the republic. He relied upon Stalin's words: "Get rid of the Hungarians now; you will have such a favourable opportunity never more! Get rid of all of them!" as well as upon his own belief that such an opportunity of getting rid of the Hungarians will not be available any more. ${ }^{24}$ According to the letter of Pavel Horváth, a statistician, and Anton Granatier, President of the Slovakian League and representative of the Democratic Party, Šrobár's proposal was joined also by the Presidium of the Slovak National Council (SNR) and by Prime Minister Zdeněk Fierlinger at the meeting held on 13 April 1945. Both of them asked President Edvard Beneš for audience and criticized Šrobár's proposal there. ${ }^{25}$ The criticism

22 For more details see: ŠUTAJ, Štefan: Mad'arská menšina na Slovensku v rokoch 1945-1948, Bratislava 1993.

23 NA, f. London Archive, card file 25. Message sent by Smutný to Minister Ripka about Edvard Beneš' meeting with Molotov from 23 March 1945.

24 NA, f. 100/24, vol. 45, etc. 856. The whole document was published for the first time in: ŠUTAJ, 1993, 181-183.

25 AÚTGM, f. Edvard Beneš II., card file 331. Record of observations on displacement of Hungarians, submitted 
was directed against the solution method proposed by Šrobár. They asked that the issue of the Hungarian minority should be solved in civilized manner, based on an agreement of population exchange between Czechoslovakia and Hungary. The authors summarized what the solution according to Šrobár's proposal would look like. Displacement would be decided by district commissions; the population would have to leave behind all property. "The deported persons will be escorted by the army across the border. Once beyond the border, they will be left to their fate." ${ }^{26}$ According to P. Horváth and A. Granatier, Šrobár's proposal could not be agreed with. "The proposal does not speak about agreement with the Hungarian government. The authors think that only our state has right to deal with this issue, in a manner that is only at our convenience." They pointed out that it would be problematic to call Hungarian parties irredentist, and that it would be problematic to waive civil rights "we have consistently emphasized so far". They asked that "the attitude of the Presidium of the Slovak National Council is thoroughly reviewed and brought into accord with the international position of the Czechoslovak Republic in the past, in the present and in the foreseeable future. We must accentuate the good name of the restored state, the good name of our nation and future peace, as well as friendly relations with neighbour states and nations. If we have won the war, let's strive to win also the peace." ${ }^{27}$ At the same time, they informed the president that they had been dealing with the issue for a long time and that they disposed of a modified proposal for solution of the Hungarian issue, based on population exchange between Czechoslovakia and Hungary and repatriation of compatriots from Romania, Bulgaria and Yugoslavia. ${ }^{28}$

However, there was not only the matter of attitude towards minorities, building of a national state without national minorities, but also the issue of guarantee of borders, international position of the Czechoslovak Republic, as well as other issues related to the position of Czechoslovakia and Hungary in international policy. In view of the preceding promises and agreements, it was obvious that the most serious issues would be decided by the Peace Conference, and therefore the necessary frameworks for lodging of the most important requirements had to be created. Pragmatic politicians must have been aware that the world diplomacies, including the Central European, were in for talks that could determine the position of states (nations) for a long period, and if the respective representations didn't make use of them, they could harm not only their positions of that time but the future fate of their states.

Czechoslovakia, with its Košice Government Programme, started unambiguously the policy of building a national state of Czechs and Slovaks, which could be seen in all conceptual matters related to the preparation of the Peace Conference. In mid-1945, the attention of the Czechoslovak and Hungarian diplomacy was focused on the talks of the Powers in Potsdam, from which the ČSR awaited joint action towards the Germans and the Hungarians. On 3 July 1945, the Czechoslovak government approached the Allied Powers asking to include also the transfer of the Germans and Hungarians from Czechoslovakia into the

at the audience with E. Beneš on 4 May 1945 by P. Horváth and A. Granatier.

26 AÚTGM, f. Edvard Beneš II., card file 331. Record of observations on displacement of Hungarians from 4 May 1945.

27 Ibidem.

28 Ibidem. 


\begin{tabular}{c|cr|c}
\hline 70 & $\begin{array}{c}\text { ARTICLES } \\
\text { Štefan ŠUTAJ }\end{array}$ & $\begin{array}{r}\text { Transfer of Hungarians from Slovakia in Gzechoslovak } \\
\text { Politics hefore Paris Peace Conference 1946 }\end{array}$ & \\
\hline
\end{tabular}

preparations of the discussions about future Europe. It asked for consent to displace 2-2,5 millions of Germans and 400 thousand Hungarians "through population exchange for the Slovaks living in Hungary" ${ }^{29}$ trying to get the issue of transfer of the Hungarians from the ČSR to international forum again. The Potsdam Conference took place from 17 July to 2 August 1945. It established the Council of Foreign Ministers, consisting of representatives of the Union of Soviet Socialist Republics, United States of America, Great Britain, France and China, empowered to prepare peace treaties with Italy, Romania, Bulgaria, Hungary and Finland. The council was authorized to invite representatives of the state concerned by the discussed issue to the talks. It was also agreed to suggest dissolution of the European Advisory Commission that had played a significant role when specifying the conditions of peace with the defeated countries.

Point $X$ of the report from the Potsdam Conference concerned adoption of peace treaties with satellites of Germany. Point XII dealt with the transfer of Germans from Czechoslovakia, Poland and Hungary. All agreements were included in the report from 2 August 1945. The issue of the Hungarian minority in Czechoslovakia did not get to the agenda, and it even should not get there. Afterwards, the Czechoslovak diplomacy strived, through memorandums and special talks, to obtain a declaration from the Powers that the conclusions of the Potsdam Conference on transfer could be applied also on population of Hungarian nationality in Czechoslovakia. The Czechoslovak memorandums were answered by American Foreign Minister James F. Byrnes by the instruction sent to the embassies to Prague and Budapest for Laurence A. Steinhardt and Arthur Schoenfeld, ordering them to inform the Czechoslovak and Hungarian governments that the decision of the Potsdam Conference on transfer of Germans did not apply to the Hungarian minority in the ČSR. By that, the discussion of that topic was concluded. He suggested that the USA would welcome if both governments elaborated together plans for arrangement of minority issues and submitted them to the Allies ${ }^{30}$ and also that unilateral displacement of Czechoslovak Hungarians was supported only by the Soviet Union and Britain and that the Americans were against it. ${ }^{31}$ The results of the Potsdam Conference finally decided of the duality of solution of the German and Hungarian issue in Czechoslovakia, which was confirmed also by the decision of the Powers that the Peace Conference would deal only with agreements with the satellites of Germany. At the same time, the Western Powers outlined resolutely the range in which the diplomacy of both states could act.

The Czechoslovak and Hungarian talks acquired a new dimension by that. Hungary responded negatively to potential unilateral displacement. It was shown for example by the secret message of the Ministry of the Interior from 8 November 1945, sent to the Czechoslovak Foreign Ministry and assessing attitudes of important representatives of Hungarian political parties, Zoltán Tildy, Matyás Rákosi, Árpád Szakasits and others who refused resolutely the transfer of the Hungarians from Czechoslovakia. The atmosphere

29 IRMANOVÁ, Eva: Postavení mad’arské menšiny na Slovensku po roce 1945, in: Česko-slovenská historická ročenka, Brno 2002, 26; ČIERNA-LANTAYOVÁ, 2009, 27-28. The memorandum is mentioned also in KUKLÍK, Jan: Britská diplomacie a československé požadavky na mírovou smlouvu s Mad’arskem, in: Mierové zmluvy v kontexte geopolitiky, KLIMKO, Jozef - MICHÁLEK, Slavomír a kol., Bratislava 2013, 205-206.

30 LANTAYOVÁ-ČIERNA, 2009, 28; 85th telegram to Steinhart and Schoenfeld from 19 October 1945.

31 ROMSICS, Ignác: Parížska mierová zmluva z roku 1947, Bratislava 2008, 172. 
was probably characterized the best by Mátyás Rákosi's statement that "the whole plan of expulsion of the Hungarians from Slovakia was unhappy and unjust". ${ }^{32}$ They considered the number of Slovaks in Hungary insufficient as compared to the number of Hungarians in Slovakia and assumed that the Slovakians from Hungary would not be interested in moving to Slovakia. Dalibor Miloš Krno, the Czechoslovak plenipotentiary at the Allied Inspection Committee, submitted the Czechoslovak idea of the future of the Hungarian minority in the ČSR to Hungarian Foreign Minister János Gyöngyösi in September 1945. According to the concept, the first stage was to include exchange of Slovak Hungarians and Slovakians living in Hungary, followed by displacement of the remaining part of Hungarians. Czechoslovakia did not give the idea of displacing the Hungarians from the republic. J. Gyöngyösi objected both to displacement and to population exchange, declaring that they would agree to it only based on an international decision. He saw a solution in modification of border. ${ }^{33}$ The Hungarian representatives did not abandon the thesis of unjust border and kept considering their correction as one of the options, and the hopes of the Hungarian politicians focused more and more to the forthcoming Peace Conference. ${ }^{34}$

In that stage, the Czechoslovak politicians considered realistic to focus on provision of population exchange between the ČSR and Hungary that occurred among potential forms of solution of the minority issue. Contrary to the Hungarian diplomats that perceived the potential exchange as unavoidable evil and, in view of the belief of their documentation, did not consider it realistic, the Czechoslovak side considered the population exchange one of the first steps to achieve Slovakization of the "Slovak south" and believed to be supported by the Allies in order to complete the ethnically clean Slavic "national" state of Czechs and Slovaks.

That could be seen also in the talks on population exchange between Czechoslovakia and Hungary in December 1945. The above stated differences were unambiguously declared there and, in the first stage, resulted in interruption of the talks. ${ }^{35} \mathrm{After}$ the talks of December 1945, the population exchange was a partial solution for Czechoslovakia. At the talks with Hungary held on 4 December 1945, V. Clementis, adhering to the idea of the Czechoslovak politicians of concentration of compatriots from different parts of the world, presented the opinion that in case of successful population exchange, Czechoslovakia would not be interested in the Slovaks who remained in Hungary, as it would expect them to assimilate. ${ }^{36}$ At the talks held on 5 December 1945, V. Clementis expressed the belief that the population exchange would constitute only the beginning of relocation and that the displacement of the Hungarians was the only solution of mutual conflicts: „We keep holding the opinion that we will succeed in achieving such agreement in next stage, that Hungary will take over

32 AMZV, f. General secretariat of Jan Masaryk and Vladimír Clementis (GS-A), kart. 173.

33 ROMSICS, 172.

34 KUKLÍK, 209.

35 For more details see: ŠUTAJ, Štefan: Czechoslovak Government Politics and the Population Exchange, in: Memories and Reflections of the Dispossed, MOLNÁR, Imre - SZARKA, László (eds.), Komárom 2010, 83-92; ŠUTAJ, Štefan: Výmena obyvatel'stva medzi Československom a Mad'arskom a Parížska mierová konferencia, in: Mierové zmluvy v kontexte geopolitiky 20. a 21. storočia, KLIMKO, Jozef - MICHÁLEK, Slavomír (eds.), Bratislava 2013, 220-243.

36 AMZV, f. Legal Department (PO), card file 119. 


\begin{tabular}{c|cr|c}
\hline 72 & $\begin{array}{c}\text { ARTICLES } \\
\text { Štefan ŠUTAJ }\end{array}$ & $\begin{array}{c}\text { Transfer of Hungarians from Slovakia in Gzechoslovak } \\
\text { Politics hefore Paris Peace Conference } 1946\end{array}$ & \\
\hline
\end{tabular}

Hungarians exceeding the quota implemented by the exchange, that it would take them over under all beneficial economic conditions, so that the Hungarians remaining here will never more constitute a problem that could lead between us to conflicts with revisionist character." He believed that the problem would be solved, and as long as there was a chance that a border modification could occur, he did not expect any change of the Hungarian attitude. But he assumed that the peace talks would conclude that chapter of mutual relations. "I don't believe that in the future, any kind of revision against Czechoslovakia had chance of success, that is... from the Hungarian side, ... as long as there are such hopes, our relation will never be as it should be. But if, after a new review of the whole problem, if our governments achieve a complete agreement, regardless of future peace talks, the peace talks would take notice of the bilateral agreement. If not so - our attitudes will be so different; both of us would have to apply our arguments on international and national forums, and the result would consist in re-worsening of our mutual relations, as the conference would decide rather in our favour than in favour of Hungary. And Hungary would be in position of a defeated state again, a state that feels its grievance." ${ }^{37}$

At the talks of 5 December Clementis substantiated the unwillingness of the Hungarians to agree to a partial agreement of exchange by tactical play in connection with future peace talks: "There is obvious tendency of the Hungarians to wait until the decision of the Peace Conference and develop campaigning there - as I have mentioned already. So why should we bargain; we will saddle the Peace Conference with everything." ${ }^{38}$

At the December talks, J. Gyöngyösi formulated unambiguously the opinion that in case the Hungarian requirements on assurance of civil and national rights of the Hungarians who stay in Czechoslovakia were not accepted, the only solution consisted in transferring the Hungarians including the territory they lived in. ${ }^{39}$

After the failed talks from 3 - 6 December 1946, information was sent by the Czechoslovak Foreign Ministry to all representative offices in Prague. The information stated the Czechoslovak arguments for displacement of the Hungarian minority from Czechoslovakia. First of all, they noted the alliance of Hungary with Germany, from the beginning till the very end. The second thesis stated the inevitable displacement of the Hungarians who had acted with hostility against the ČSR, wherefore Czechoslovakia "wants and must get rid of the Hungarian minority". The third point noted that during the crisis, the Germans and the Hungarians acted in the same way towards the ČSR, "and therefore no difference can be made between them - as for the displacement". The letter expressed willingness to negotiate about the modalities of the displacement "in maximally humane spirit". ${ }^{40}$

The Report from 12 December 1945 was enclosed to the letter for the embassies in Prague. The Report pointed out that Czechoslovakia had unambiguously declared that its goal consisted in getting rid not only of the German, but also of the Hungarian minority, and that it was trying to push it out from the perspective of its own safety. It stated that

37 AMZV, f. PO, card file 119, Minutes of meeting from 5 December 1945, 16,30.

38 Ibidem.

39 AMZV, f. PO, card file 119. Minutes of the second meeting (the Hungarian part).

40 NA, f. Office of Presidium of the Government (ÚPV), kart. 1112, Letter of the Foreign Ministry to representative offices, delivered to the Soviet, American, English, French and Yugoslavian representation, from 12 December 1945. 
after the Potsdam Conference that had not dealt with the Hungarian issue, Czechoslovakia had focused on bilateral talks with the interim Hungarian government, striving to solve controversial issues. In that respect, Czechoslovakia also assumed that those who were not included in the population exchange would be subject to the transfer, except for those who obtain Czechoslovak citizenship, but without having any minority rights. V. Clementis' words from the beginning of the talks were pointed out - that the issue of the Hungarian minority had to be finally solved and that it could never be carried out "in form of border modification in favour of Hungary" ${ }^{41}$ He had also alerted that Hungary had not met its reparation commitments resulting from the Armistice Agreement. On the contrary, the Hungarian Foreign Minister said that transfer was unacceptable and conditioned the population exchange by protection of civil rights for the Hungarians who stayed in Czechoslovakia or by relocation of population including the territory. Clementis expressed the belief that the Hungarians obviously tried to wait for the talks of the Peace Conference. At the end of the Report, he stated that the talks with the Hungarian side had been interrupted due to inflexible attitudes of the partners, because "the solution of the issue of Hungarians in Slovakia cannot and never will be carried out through border modification in favour of Hungary. Any revision constitutes inadmissible aggression for Czechoslovakia." 42 According to the information about the talks submitted by V. Clementis to Minister J. Masaryk (and to "Respectable Sirs"), Czechoslovakia was willing to give up confiscation measures, not to carry out relocation and displacement and perform such measures that socially weak population would not suffer, including payment of financial aid and pensions to those "who are Hungarian citizens today, but in the past enjoyed Czechoslovak pension". ${ }^{43}$ But Hungary required "cancellation of all legal measures concerning the Hungarian population" ${ }^{44}$ which, according to Clementis, could not be effectuated.

The Hungarian diplomats also submitted their view of the issue to the Winning Powers. On 26 January 1946, Foreign Minister János Gyöngyösi handed over a complete memorandum to the British representation to Budapest (that was handed over also to representatives of the USSR and the USA) in which, according to the British representative at the Budapest government, Alvary Frederic Gascoigne ${ }^{45}$, there was nothing new and which was based on injustice of Trianon. Gascoigne himself did not consider it too appropriate for the Hungarian government to present its opinions in such form and at that moment. The memorandum also suggested a special procedure of adoption of the Peace Treaty with Hungary, in form of an expert commission. On 7 February 1946, the document was completed by another Hungarian note requiring just peace allowing cooperation with neighbours. ${ }^{46}$

41 AMZV, f. PO, card file 119. Note sent to embassies in Prague.

42 Ibidem. The Report in Czech version, from December 1945, without date, entitled "Negotiations with Hungarian delegation", discussed the issue of the talks offered to Hungary with regard to transfer of population of Hungarian nationality.

43 AMZV, f. PO, card file 119. Speech of Secretary of State V. Clementis with regard to termination of talks with Hungary in December 1945, without date.

44 lbidem.

45 He was British diplomatic representative to Budapest from spring 1946 to spring 1946. See: ROMSICS, Ignác: A brit külpolitika és a „magyarkérdés”, 1914-1946, in: Helyünk és sorsunk a Duna-medencében, Budapest 2005, 39-131.

46 KUKLÍK, 210. 


\begin{tabular}{c|cr|c}
\hline 74 & $\begin{array}{c}\text { ARTICLES } \\
\text { Štefan ŠUTAJ }\end{array}$ & $\begin{array}{r}\text { Transfer of Hungarians from Slovakia in Gzechoslovak } \\
\text { Politics hefore Paris Peace Conference } 1946\end{array}$ & \\
\hline
\end{tabular}

After the end of World War II, Czechoslovakia should be developed as a national state of the Czechs and the Slovaks, without non-Slavic minorities. Due to such concept of solution of the minority issue, the problem of the Hungarian minority was to be solved radically, by population exchange between Czechoslovakia and Hungary and transfer of the whole Hungarian minority away from the ČSR. In case such version of solution failed, internal political solutions of the issue were considered, including relocation of population of Hungarian nationality from Southern Slovakia to Northern parts of Slovakia, dehungarization of towns, relocation of Hungarians to Bohemia and Moravia to areas from where Germans had been expatriated and re-Slovakization. ${ }^{47}$

Hungary refused to allow transfer of population of Hungarian nationality from Slovakia and considered unrealistic the announced population exchange between Czechoslovakia and Hungary. Under pressure of the international community and after complicated negotiations between the representatives of Czechoslovakia and Hungary, the Agreement of population exchange between Czechoslovakia and Hungary (Agreement) was signed on 27 February $1946 .{ }^{48}$

The basic problem of the signed Agreement consisted in the fact that it was not implemented even after long months. According to K. Vadkerty, the fulfilment of the exchange agreement "was postponed by the Hungarian government, substantiating it by protection of economic interests of the Slovak Hungarians to be displaced. The vigorous conditions of the Hungarian government paralyzed the Czechoslovak government that accused it of unsubstantiated postponement of realization" ${ }^{49}$ Czechoslovakia expected realistic and fast fulfilment of the Agreement and created all technical conditions for it. It performed registration of Slovaks and Czechs in Hungary through the ČSPK acting in Hungary. By 26 August 1946, it prepared selection of persons of Hungarian nationality intended for displacement..$^{50}$ It created the displacement infrastructure in form of specialized apparatus, ČSPK acting in Hungary and structures of Colonization authority (hereinafter referred to as OÚ) in Bratislava that was to provide for the exchange on the territory of Slovakia. Hungary was lacking not only a similar exchange structure but also willingness to start the population exchange, and it expected that by negotiating with

47 For more details see: ŠUTAJ Štefan: Mad'arská menšina na Slovensku v rokoch 1945-1948. Bratislava 2012; ŠUTAJ, Štefan: Nútené presídlenie Mad’arov zo Slovenska do Čiech. Deportácie obyvatel'stva mad'arskej národnosti zo Slovenska do Čiech po druhej svetovej vojne. Prešov 2005.

48 For more details on this issue see for example: VADKERTY, Katalin: A belsö telepítések és a lakosságcsere. Bratislava 1999; VADKERTY, Katalin: A csehszlovák-magyar lakosságcsere hivatalos szlovák értékelése, in: Regio, 4, 1993, 3, 119-139; MOLNÁR, Imré - SZARKA, László (eds.): Otthontalan emlékezet. Komárom 2007; POPÉLY, Árpád: Plány na vysídlenie mad'arského obyvatel'stva v rámci výmeny obyvatel'stva medzi Československom a Mad’arskom, in: Fórum. Spoločenskovedná revue, Šamorín 2009, 47-67. BOBÁK, Ján: Výmena obyvatelstva medzi Česko-Slovenskom a Mad'arskom (1947-1948), Bratislava 1994; KUGLER, József: Lakosságcsere a délkeletalföldön 1944-1948, Budapest 2000; PARÍKOVÁ, Magdaléna: Reemigrácia Slovákov z Mad’arska v rokoch 1946-1948, Bratislava 2001; ŠUTAJ, Stefan: Magyarok csehszlovákiaban 1945-1948 között - kisebbségkutatás, Budapest 2008; VADKERTY, Katalin: Mad’arská otázka v Československu 1945-1948, Bratislava 2002 and other works.

49 VADKERTY, 2002, 59.

50 For more details see e.g. POPÉLY Árpád: Výmena obyvatel'stva medzi Československom a Mad’arskom a menné zoznamy Mad'arov určených na presídlenie, in: Človek a spoločnost', XII, 2009, 1, URL: http://www.saske. sk/cas/zoznam-rocnikov/2009/1/5850/. 
the representatives of the Allies before the Peace Conference and in its course, actual displacement would be avoided. It came out that many formulations of the Agreement were not unambiguous and both parties interpreted them in different ways, which created conditions for conflicts and misunderstanding. The Czechoslovak government blamed the Hungarians for nonfulfillment of the Agreement. The Hungarians defied the Agreement and searched all possible substantiations to avoid its fulfilment. At the same time, by failing to meet the commitments assumed in the records, it created conditions for objections of the Hungarians. The dominance of the Czechoslovak diplomacy as against the Hungarian was confirmed in international relations; a new strategy confirming the effort to get rid of the Hungarian minority was created. But at the same time, the number of persons registered for displacement in Hungary confirmed the "inevitability" of finding other means to complete "cleaning" of Slovakia from the Hungarians - by re-Slovakization, assimilation or transfer. The Czechoslovak politicians concentrated on preparation of peace treaties, as they could find support for radical solutions only in them.

The attention of the Czech diplomacy focused on international guarantees of displacement of the Hungarian minority from the ČSR, while the initiatives of the Hungarian diplomacy were focused on protection of Hungarian minorities in neighbour countries and on provision of their national rights. They tried to prevent displacement of the Hungarians from the ČSR and to achieve potential border modification based on "ethnographic" concept. ${ }^{51}$ In that spirit, both countries developed diplomatic activities towards the Soviet Union and the western countries, to improve their chances at the peace talks. ${ }^{52}$

The elaboration of the peace treaties were in responsibility of the Council of Foreign Ministers of the Powers, constituted based on Art. 2 of the Potsdam Declaration. The treaties were to be submitted to United Nations that had participated in the war. The subsequent meeting of the Council of Foreign Ministers in London took place from 11 September to 2 October 1945. Both the Czechoslovak and the Hungarian diplomats strived to get their interpretations of the issue to the Council of Foreign Ministers. In the Hungarian diplomacy, in spite of the fact that it was "corrected" by the Allied Inspection Committee controlled by the Soviets, groups of Hungarian politicians of "civil" (non-communist) orientation sought way and support of western allies. Similarly, the West sought ways to influence the situation in Hungary and to win it for pro-Western orientation. The Hungarian diplomacy tried to make use of it before the Peace Conference. The western diplomats, ambassador to Moscow W. A. Harriman and ambassador to Budapest A. Schoenfeld, visited Foreign Minister J. Gyöngyösi on 9 October 1945. A two-hour talk took place in presence of members of his cabinet. He informed Schoenfeld about the records of atrocities from Slovakia and familiarized him with the prepared documentation material for the Peace Conference. István Kertész, chef of the political section preparing documentation for the

51 For more details see e.g. ŠUTAJ, Štefan: Variace stop Trianonu v politické paměti, in: Trianonská smlouva. Devadesát let poté, DEJMEK, Jindřich - LOUŽEK, Marek (eds.), Praha 2010, 69-97; ŠUTAJ, Štefan: Trianon a szlovákaia történelmi emlékezetben, in: Limes, XXIV, 2011, 1, 71-86.

52 For more details see e.g. ŠUTAJ, Štefan: A mad’ar külpolitika lépései a párizsi békekonferencia előtt - a csehszlovák diplomácia szemszögéből, in: A Közép-Európaiság dicsérete és kritikám, FEDINEC, Csilla - ILYÉS, Zoltán - SIMON, Attila - VIZI, Balázs (szerk.), Pozsony 2013, 613-634; ŠUTAJ Štefan: Rokovania o mieri s Mad’arskom a ich vplyv na postavenie mad'arskej menšiny na Slovensku, in: Acta Universitatis Carolinae. Iuridica, 1, 2013, 277-299. 


\begin{tabular}{l|cr|c}
\hline 76 & $\begin{array}{c}\text { ARTICLES } \\
\text { Štefan ŠUtaJ }\end{array}$ & $\begin{array}{r}\text { Transfer of Hungarians from Slovakia in Gzechoslovak } \\
\text { Politics before Paris Peace Gonference 1946 }\end{array}$ & \\
\hline
\end{tabular}

Peace Conference, drew the ethnic border by the 1910 census on the map. Subsequently, there were talks about whether Hungary could require from the Powers that the arbitration area should be considered a disputed territory under common administration. The border variants envisaged by the Hungarian Foreign Ministry were approximately identical to the Vienna Awards border. ${ }^{53}$ But even after having listened to such proposals, the western diplomats did not support the Hungarian activities concerning border modifications.

In December 1945, another meeting of the Council of Foreign Ministers was held in Moscow. It specified the procedure of conclusion of peace treaties with former Hitlerian satellites, adopted the method of elaboration of agreements, their signing and ratification and specified the date of start of the Peace Conference - May 1946. In Moscow it was decided, in compliance with the resolution of the Potsdam Conference, that the peace treaties will be elaborated by representatives of the Powers that had accepted the capitulation of the respective defeated state. ${ }^{54}$

The Hungarian diplomatic activities before the Peace Conference started by an offensive in the Soviet Union. ${ }^{55}$ The most important tasks included avoidance of unilateral transfer of Hungarians from Czechoslovakia. Molotov and Stalin received J. Gyöngyösi and F. Nagy in Moscow. The Hungarians informed them that Hungary could not accept a "mass" of 200 thousand Hungarians from Czechoslovakia and that they wanted the issue of position of the Hungarian minority in Czechoslovakia to be included in the Peace Treaty. At the end of the talks, Stalin emphasized that the issue of provision of civil rights to Hungarians in Czechoslovakia was justified, that the USSR would support it but could not guarantee success. ${ }^{56}$

On 25 April 1946, the negotiations of the conference of foreign ministers of the Powers started in Paris on the issue of conclusion of peace treaties with former allies of Germany - Bulgaria, Finland, Hungary, Romania and Italy -, to decide about further development of Europe and about termination of World War II. Strategic issues of peace treaties had to be decided, but it also had to be decided whether and how the cooperation of the Winning Powers would go on. A failure of the conference would have been perceived as failed effort for peaceful arrangement of the world. The delegations of the individual countries were led by Georges Bidault (France), James F. Byrnes (USA), Ernest Bevin (Great Britain) and Viacheslav M. Molotov (USSR). The sessions were interrupted on 15 May; their second round started on June 15 and ended before the Peace Conference.

Before the Foreign Ministry prepared materials on Czechoslovak demands on the Peace Conference, the memorandum with demands for the Powers had been prepared and handed in, which was obviously related to the prepared session of the Council of foreign

53 LANTAYOVÁ-ČIERNA, 2009, 85.

54 PETRUF, Pavel: Československo na mierovej konferencii v Parízi roku 1946, in: Historický časopis, 33, 1985, 1, 68. According to D. M. Krno, the talks were held on Christmas and Bevin, Byrnes, Molotov, Bidault attended it. See: KRNO, M. Dalibor: Paríz 1946. Pripravoval sa mier s Mad'arskom, Praha 1947, 10.

55 For more details of the talks see: ŠUTAJ, Štefan: Československé a madarské diplomatické aktivity pred Parižskou konferenciou 1946 (z pohl'adu československej politiky a diplomacie), in: Slovensko v labyrinte európskych dejín, MICHÁLEK, Slavomír a kol., Bratislava 2014, 658-684.

56 MURAŠKO, Galina Pavlovna: Vostochnaya Evropa v dokumentakh rossiyskikh arkhivov 1944-1953. Moscow/ Novosibirsk 1997, 402-416. The prevarications of the Soviet diplomacy and promises for both sides were pointed out both by Slovak and by Hungarian historiography. 
Ministers. On 3 April 1946, the Czechoslovak memorandum on the Peace Treaty was passed separately to Gladwy Jebb, the British diplomat in Paris, who handed it to Lord Hood, member of the British delegation for the Peace Conference. The memorandum with two annexes and two maps was passed by V. Clementis to Mr. Nichols, the British ambassador to Prague. ${ }^{57}$ Similar documents were passed also to representatives of the USA and the URSS. The basic requirements, additionally to explicit recognition of blame of Hungary, included de-recognition of the Munich Agreement and Vienna Awards, recognition of borders before Munich and waiver of the idea of Saint-Stephen Crown. The Peace Treaty should, additionally to population exchange, confirm also transfer of 200 thousand Hungarians and re-Slovakization, restitution of archives and monuments of arts, claim to reparations and incorporation of the bridgehead area of Bratislava. P. B. Nichols supported the Czechoslovak idea to combine displacement and population transfer and criticized some measures of SNR against the Hungarian minority, particularly expelling of the Hungarians. ${ }^{58}$

Czechoslovakia pinned great hopes on the Soviet Union and develop great diplomatic activity in this direction. Before the conference started on 25 April 1946, Jan Masaryk, the Foreign Minister of the ČSR addressed letters from Paris to V. M. Molotov, the Foreign Minister of the USSR, to G. Bidault, the Foreign Minister of France, and to E. Bevin, the state secretary of the Foreign Minister, asking that the issue of displacement of the Hungarian population from the ČSR should be included in the agenda ${ }^{59}$ and that Czechoslovakia should get an opportunity to express its view on that issue. At the same time, Czechoslovakia announced that it had appointed a special empowered envoy to Paris, Vavro Hajdu, the head of Foreign Ministry department of preparation of materials for preparation of materials for the peace negotiations, who would be available to the Council of Foreign Ministers in Paris. Masaryk, when handing over the memorandum to Nichols on 25 April 1946, emphasized the transfer and the rectification of the border near the bridgehead area of Bratislava. ${ }^{60}$

The Czechoslovak demands on transfer were accepted by the Allies, with understanding, but not with enthusiasm and absolutely not with unambiguous support, similarly to the period of the Potsdam Conference. On 29 April 1946 Minister V. Molotov received in Paris Jindřich Nosek (the Czechoslovak ambassador to Paris) and V. Hajdu (head of Department " $M$ " of the Foreign Ministry). The talks focused on the transfer of the Hungarians from Czechoslovakia. For the Czechoslovak diplomacy, it was one of the essential issues for the upcoming Peace Conference. As the Secretary of State, Vladimír Clementis, states in his message, Molotov was restrained, suggested that the issue should be solved by a bilateral agreement with the Hungarians and manifested that the solution of the issue would depend also on the attitude of the English and the Americans. ${ }^{61}$ In subsequent talks,

57 KUKLíK, 207.

58 KUKLÍK, 208-209. For more details see: KUKLÍK, Jan - NĚMEČEK, Jan. Zpráva britské diplomacie z Prahy $\checkmark$ roce 1945. Praha 2010.

59 Vopros o peresilenii vengerskogo naseleniya iz Chekhoslovakii - la question du transfert magyare de la Tchécoslovaquie - the question of the transfer of the Hungarian population from Czechoslovakia.

60 KUKLíK, 209.

61 AMZV, f. GS-A, card file 167. V. Clementis' information Transfer Mad'arov na mierovej konferencii. V. Hajdu 


\begin{tabular}{c|cc|c}
\hline 78 & $\begin{array}{c}\text { ARTICLES } \\
\text { Štefan ŠUTAJ }\end{array}$ & $\begin{array}{r}\text { Transfer of Hungarians from Slovakia in Gzechoslovak } \\
\text { Politics hefore Paris Peace Conference 1946 }\end{array}$ & \\
\hline
\end{tabular}

e.g. with Hubert Ripka, the Foreign Trade Minister, the Soviet representatives expressed support to Czechoslovak ambitions to displace 200 thousand Hungarians. ${ }^{62}$ On 23 June 1946, the Czechoslovak ambassador to Paris, while the Paris talks of the Foreign Ministers continued, sent another letter to V. M. Molotov, emphasizing once more the Czechoslovak proposals from the letters from 25 April 1946. ${ }^{63}$

The British diplomacy also considered the transfer requirements legitimate, but did not want to support them or to submit them at the Peace Conference. At the Research Department, particularly under the influence of prof. C. A. Macartney, the conditions were not favourable to the Czechoslovak proposals. Macarthey, with reference to the UN Charter and Atlantic Charter, considered the displacement of the Hungarians inadmissible, while seeing "a lot of common sense in the Hungarian demands. ${ }^{64}$

Similarly to the talks about the Armistice Agreement, the Czechoslovak diplomats tried in vain that the transfer of the Hungarians was included in the agenda of the Foreign Minister Council and thus in the draft of Peace Treaty with Hungary. The dispatch sent by V. Clementis to Paris on 10 May 1946, to the Czechoslovak diplomats Jindrich Nosek, Vavro Hajdu and Juraj Slávik, stated that according to the past information and talk with Andrei J. Vyshinsky, he concluded that the Czechoslovak transfer proposal could not be integrated in the agenda of the next session of the Council of the Four. He stated: "continue your information work and direct it to get into the agenda of the session of the Four before the plenum of the conference." They were to inform the officers and ministers about the procedure and further information materials were to be delivered to them. ${ }^{65}$

Immediately before the conference, the peace treaties were discussed in the sessions of the Foreign Minister Council in Paris, from 15 June to 12 July 1946. The principles agreed on the talks were to be unchangeable. After the talks, the orientation of talks and negotiations had to be changed. The result consisted in immediate adaptation of the Czechoslovak requirements to the development of the talks of the Powers, which was manifested in the modification of the Czechoslovak requirements from 12 July 1946. Also the strategies of the steps of the Czechoslovak diplomacy were adapted. It was necessary to search partners for broader cooperation among 21 countries that were to participate in the Peace Conference as winning and cooperating countries, even if the crucial role of the Council of the Four Foreign Ministers was preserved.

Even in the last months, the Czechoslovak diplomacy could not achieve that the displacement was discussed in the Foreign Minister Council or that a Czechoslovak representative could speak at the Council. The attitudes of Foreign Ministers Bevin and Byrnes were considered

even asked V. Clementis not to send "two sirs"to Paris yet. In spite of that urging, he decided that Juraj Slávik should go to Paris and to try to "everything what was needed in Anglo-Saxon line". (AMZV, f. GS-A, card file 65, Letter of V. Clementis to V. Hajdu from 1 May 1946). According to that letter, the British diplomatic representative at the interim government, A. Gascoigne, tried to convince the Hungarian government to build good relations with the neighbours, criticized Great Hungarian thinking and revisionism ideas, warned against financial and economic burden resulting from reparations but did not support the Czechoslovak national policy.

62 BARNOVSKÝ, 158-159

63 AMZV, f. GS-A, card file 148. Letters to V. M. Molotov, E. Bevine and G. Bidault, Foreign Ministers, from 25 April 1946.

64 KUKLÍK, 210-211.

65 AMZV, f. GS-A, card file 87. V. Clementis' dispatch from 10 May 1946. 
the biggest obstacle to assertion of the Czechoslovak ambitions. ${ }^{66}$ The report from 9 July 1946 stated that the issue of transfer would not get to the talks of the Foreign Ministers of the Powers before the Peace Conference, in spite of energetic activity of the Czechoslovak diplomats and their meetings with the English, American and French partners and articles submitted to world press agencies. ${ }^{67}$ Similarly, Minister J. Gyöngyösi also tried without success, through diplomatic channels, for Hungary to be allowed to present its view on the issue before the Council of the Four. ${ }^{68}$ Before start of the conference in Paris, while the Czechoslovak government delegation stayed in Moscow from 22 to 26 July 1946, V. M. Molotov declared that the Soviet delegation would support the Czechoslovak proposal for transfer of the Hungarians at the Peace Conference. ${ }^{69}$ On the other hand, before the Peace Conference, V. Molotov refused to talk with the Hungarian Foreign Minister ${ }^{70}$ but in spite of that, "the delegations of the United States of America, Great Britain and Australia assumed the task to convince the conference not to adopt any provision that would authorize Czechoslovakia to perform unilateral displacement of the Hungarian minority,..." ${ }^{\prime 71}$

Immediately after the session of the Council of the Four ended, the Czechoslovak Government, based on the proposal of the Foreign Ministry from 27 April, adopted the resolution from 12 July 1946 on Czechoslovak requirements on the Peace Conference and empowered the Czechoslovak delegation „to present them there and possibly, according the situation emerging there, a) to adapt them to changed conditions or b) to modify them as needed or c) to waive individual requirements in total or in part". ${ }^{72}$

The resolution was divided into 12 parts, including the most important "political" requirements of "de-recognition" of the Munich Agreement and of the "Vienna Award" including all their consequences; recognition of the Czechoslovak border defined by the resolutions of Versailles, Trianon and St. Germain; waiver of irredentist and revisionist policy and concept of St. Stephen Crown; restoration of legal situation to the original status before 29 September 1938; unilateral displacement of about 200,000 Hungarians from Czechoslovakia to Hungary); and from territorial requirements, expansion of the bridgehead area of Bratislava. Later, the Government Resolution was corrected "after talks with the other delegations and particularly with the delegation of the Soviet Union". Czechoslovakia decided not to require "de-recognition" of the Munich Agreement, as "it came out that it would be tactless to remind the Western Powers of Munich" and that the invalidation of the Munich Agreement is generally accepted from legal and political

66 AMZV, f. GS-A, card file 148. Letter to V. M. Molotov from June 1946.

67 AMZV, f. GS-A, card file 148. Report of J. Nosek and V. Hajdu from Paris from 9 July 1946. Dispatch No. 170/ MZV/Prague.

68 The information about the letter was published in the French Le Figaro. AMZV, f. GS-A, card file 148. Information of J. Nosek and V. Hajdu for the Foreign Ministry of the ČSR. 7. 1946.

69 KAPLAN, Karel - ŠPIRITOVÁ, Alexandra (eds.): ČSR a SSSR 1945-1948. Dokumenty mezistátních jednání, Brno-Praha 1997, 249.

70 MICHÁLEK, Slavomír: Parížska mierová konferencia 1946 a Československo (východiská, postoje, výsledky, in: Mierové zmluvy v kontexte geopolitiky 20. a 21. storočia, KLIMKO, Jozef - MICHÁLEK, Slavomír (eds.), Bratislava 2013, 193.

71 Ibidem, 195 and ff.

72 AMZV, f. GS-A, card file 167. Resolution of the Government from 12 July 1946, on Czechoslovak requirements on the Peace Conference. The materials can be found also in AMZV ČR, f. PMK, card file 1. 


\begin{tabular}{c|cr|c}
\hline 80 & $\begin{array}{c}\text { ARTICLES } \\
\text { Štefan ŠUtAJ }\end{array}$ & $\begin{array}{c}\text { Transfer of Hungarians from Slovakia in Gzechoslovak } \\
\text { Politics hefore Paris Peace Conference } 1946\end{array}$ & \\
\hline
\end{tabular}

perspective. Also the requirement that Hungary should waiver the irredentist policy and the concept of St. Stephen Crown was left out from the Resolution. It was substantiated by the fact that the Czechoslovak requirements were fulfilled by ban on revisionism, and the remaining formulations provoked "dislike of the Powers including the Soviet Union". The date of the Munich Agreement, 29 September 1938, should be replaced by the date of the Vienna Arbitration, 2 November $1938 .{ }^{73}$

After the draft of the Peace Treaty with Hungary was made public, the internal Czechoslovak comments on the Peace Treaty draft were elaborated. They were called "minor (Moscow) comments, or General comments of Czechoslovakia on preliminary Peace Treaty draft with Hungary". As the documents stated, the material had been obtained by the Czechoslovak diplomats "from a private source". The document stated that the draft "by far does not satisfy Czechoslovakia... harming strongly the interests of Czechoslovakia in this wording". It started first and foremost that the draft "does not contain provisions on the most important item of Czechoslovakia with regard to the Peace Conference, the transfer of 150000 to maximally 200000 Hungarians from Czechoslovakia". ${ }^{74}$

The second material, prepared in Czech (major Moscow comments) Pripomínky Československa k návrhu mírové smlouvy s Mad'arskem dealt with individual articles of the Peace Treaty draft. ${ }^{75}$ As the article about transfer was absent, the document stated with respect to political clauses only that Czechoslovakia would ask for displacement of 200 thousand Hungarians from its state territory at the Peace Conference.

Important for formation of opinions on the individual articles of the Peace Treaty before the Peace Conference are the minutes of meetings of the Czechoslovak delegation that had travelled to Paris already and could influence the upcoming talks by diplomatic activities on site. The meetings held on 23 July $1946^{76}$ and 25 July 1946,77 did not deal with the issue of transfer; they only stated that the ČSR would ask for displacement of 200 thousand Hungarians. Other meetings took place at the time of the talks of the Peace Conference and this article will not discuss them.

Short before the start of the Peace Conference in Paris, the Czechoslovak Foreign Ministry prepared the fundamental theses of procedure of the Czechoslovak delegation in Paris. The proposal of 15 theses was elaborated by Vavro Hajdu, head of Department "M". He sent them to Bratislava to the Secretariat of the Commission for Research of Issues of National History, ${ }^{78}$ established at the Presidium of SNR for preparation of documentation for peace talks. The activities of the Commission should be focused on preparation of argumentation for the Peace Conference in broader context of talks. The Commission

73 AMZV, f. GS-A, card file 167. Resolution of the Government from 12 July 1946, on Czechoslovak requirements on the Peace Conference; AMZV, f. GS-A, card file 167. Correction of the Resolution of the Government from 12 July 1946, on Czechoslovak requirements on the Peace Conference.

74 AMZV, f. GS-A, card file 167. Všeobecné pripomienky Československa k predbežnému návrhu mierovej zmluvy s Mad'arskom. The draft contains objections also to other issues (border, restitutions... )

75 AMZV, f. GS-A, card file 167. Připomínky Československa k návrhu mírové smlouvy s Mad’arskem

76 AMZV, f. GS-A, card file 167. Record from meeting held on 23 July 1946 (at night).

77 AMZV, f. GS-A, card file 167. Record from meeting held on 25 July 1946.

78 Its official name was Commission for Research of Issues of National History, but we can find different variants of the name in documentation. It was most frequently called the Commission for National History. 
worked as secret inter-ministerial commission for preparation of the peace talks. It had been established on the initiative of MZV and based on the resolution of the Presidium of SNR. Its first session was held on 18 December $1945 .{ }^{79}$ The president of the Commission was deputy of SNR president, Milan Polák, its chairman was Peregrín Fíša, and his deputy, Ján Svetoň. The competences of the Commission for National History were not clear also due to the fact that it worked undercover, but also due to the fact that MZV prepared the documentation for the peace talks in cooperation with other institutions ${ }^{80}$ In the materials of the Commission for National History, the issue of substantiation of the transfer was dealt with by thesis II, proposed by Vavro Hajdu and processed in more detail by Juraj Palkovič, archivist of MZV, in June 1946. Thesis II, „Czechoslovakia without transfer of remaining Hungarians", pointed out that also the Hungarian literature and statements of Hungarian politicians show that the "Hungarian minority has been tool of Hungary for territorial expansion". "... the irreconcilable, imperious and slaveholding enemy of the Slovaks constitutes substantial danger to Czechoslovakia..." "Czechoslovakia does not intend to assimilate the Hungarians against their will, and by asking for transfer of the remaining Hungarians after exchange of the Hungarians from the ČSR for the Slovaks from Hungary, it wants to solve this issue in a humane way... The issue of the Hungarians can be solved neither through untested protection of minorities, nor through problematic autonomy of this territory for which autonomy is not technically possible; it can be solved only through their natural return to their own closed ethnic national territory within the Hungary of Trianon. ${ }^{\prime 81}$

That led to Hajdu's third thesis: „There is no hope for positive attitude of the Hungarian minority to the ČSR"; 82 according to V. Hajdu, the Hungarians constituted permanent danger to the ČSR and its neighbours. „By their position, the Hungarians are led to Hungarocentric thinking and national egocentrism sui generis worldwide." That resulted in the following decision: „After experiences from two world wars, Czechoslovakia must defend itself against the Hungarians unyieldingly and relentlessly, while preserving humanity (...) In case of self-defence of Czechoslovakia against Hungary, it is a matter of Europe, higher morality and honouring of contribution of Czechoslovakia to European spiritual culture, as well as redress of suffering of the Slovaks by the Hungarians..." ${ }^{13}$

Hungary, as a defeated land, did not have the opportunity to present its positions at the initial talks of the Peace Conference; but behind the scene, particularly Paul Auer, a significant Hungarian diplomat tried to open a play in which the Czechoslovak delegation led by V. Clementis and V. Hajdu, the communist leaders, created a good background. Auer stroke particularly the western note, presenting Hungary as a country that needed protection

79 Slovenský národný archív (Slovak National Archive in Bratislava, hereinafter referred only as SNA), f. Office of the Presidium of SNR (ÚP SNR), inv. no. 247, card file 283. Minutes of the 1st meeting of the Commission for Research of Issues of National History from 18 December 1945.

80 SNA, f. ÚP SNR, inv. no. 247, card file 284. P. Fíša's letter to the Foreign Ministry. The materials of AMZV include also other versions of comments to the draft of the Peace Treaty with Hungary whose author was ambassador Lisický, as well as other version of comments by V. Hajdu and Lisický from 6 August 1946, i.e. at the time of the negotiations of the Paris Conference 1946 already.

81 SNA, f. ÚP SNR, inv. no. 247, card file 283. Czechoslovakia without transfer of the remaining Hungarians.

82 Ibidem.

83 Ibidem. Thesis III. There is not hope for positive attitude of the Hungarians towards the ČSR. 


\begin{tabular}{c|cr|c}
\hline 82 & $\begin{array}{c}\text { ARTIGLES } \\
\text { Štefan ŠUtAJ }\end{array}$ & $\begin{array}{r}\text { Transfer of Hungarians from Slovakia in Gzechoslovak } \\
\text { Politics before Paris Peace Conference } 1946\end{array}$ & \\
\hline
\end{tabular}

against the Slavic anti-communist bloc created around the Soviet representatives at the Peace Conference. Also the discrepancies in the Hungarian peace delegation in which the communist representatives were sidetracked by the activity of experienced Hungarian diplomats and the passivity and incompetence of the communist leaders at the Peace Conference created a suitable background for it. Paul Auer's opinions were made public before the beginning of the Conference in the letter addressed to Walter Lippmann in "Herald Tribune" on 21 July 1946. The opinions concerning the Czechoslovak context can be summarized in the following points: 1 . Hungary refuses the recent Molotov's statement that Hungary had little participated in beating Germany and points out the contrary statement of Admiral Voroshilov presented in Budapest. The Hungarian delegation must expose indirectly the countries with the same guilt (e.g. Slovakia) that had been in similar situation as Hungary; 2. it should be avoided that decisions punished, but that human and national rights are applied; 3 . Hungary should avoid crises and survive; 4. territorial clauses should be adopted, barriers against pushing through the communist party and the Soviet influence should be created.

Later, when talking to T. Merrill, member of the American delegation on 2 August 1946, P. Auer suggested, or pointed out that some Hungarian politicians could misuse the revisionist policy for own goals and unsolved territorial issues of people in the interim period, and at the same time that the Soviet policy made use of the opportunity to influence countries. In the talk, Auer expressed the belief that the conference would stop deportations of the Hungarians from Slovakia in the next future and that the Allied Commission would review the situation and present suggestions to the United Nations, and that the occupation armies would leave the country within 90 days after ratification of the Peace Treaty. He draw attention to penetration of Soviet economic interests to Central Europe. He particularly pointed out the situation in the Hungarian peace delegation and the fact that Elek Bolgár, communist deputy to Foreign Minister had not met the delegation in Paris due to an illness ("diplomatic illness"). Auer expressed the belief that the communist policy would not be involved in presenting the Hungarian policy in Paris. He also reminded that the draft of the Peace Treaty was considered national disaster by most Hungarians. ${ }^{84}$ The policies of both countries in relation to the transfer proposed by Czechoslovakia had been opened and both countries pinned hopes for beneficial solution on the talks of the Peace Conference. The talks of the Paris Conference lasted from 29 July 1946 to 15 October 1946. The talks of the Treaty with Hungary ended on 12 October 1946. After that, the Council of Foreign Ministers elaborated the final texts of the Peace Treaties at the New York session held from 4 November to 13 December 1946. The Peace Treaty with Hungary was signed in Paris on 10 February 1947.

The talks of the Peace Conference were based on the draft of the Peace Treaty. It was discussed by Peace Commission bodies, the plenum, political and territorial commissions, economic commissions, press and military commission. The winning and cooperating states could deliver their proposals for change of the proposed articles of the Peace

84 Paris Peace Conference 1946. Memorandum of Conversation Frederick T. Merrill-Auer of the United States Delegation, 2 August 1946, online: http://images.library.wisc.edu/FRUS/EFacs/1946v03/reference/frus. frus1946v03.i0015.pdf, 81-84. 
Treaty (amendments). ${ }^{85}$ The defeated states could be summoned to the sessions of the commission bodies only after approval of the relevant commission, and their proposals could be submitted only if some of the allied countries took charge of them. Substantial issues in connection with the Peace Treaty with Hungary were dealt with at the sessions of the Political and Territorial Commission for Hungary (Political Commission for Hungary) that could create sub-commissions for solution of partial issues at its talks.

At the time of the initial talks of the conference already, the representatives of the individual delegations who had presented the priorities of their countries started the first negotiations behind the scenes of the Conference, clarifying not only the goals but also the degree of concessions the individual countries were willing to undergo.

It must be emphasized that the peacemaking function of the Conference for next generations was put on the first place, not only in the speeches of the leaders of Big Four. The speech of the first delegate of the Dutch delegation, Boletzalaer von Oosterhout, included the statement that "only God can punish. We don't award punishment. We protect the future." His speech, as well as that of other representatives of the winning countries, pointed out the role of prevention in work of the Peace Conference..$^{86}$

Czechoslovakia presented the proposal for transfer of the Hungarians from the country in its amendment C.P. Gen. Doc 1.Q.5. ${ }^{87}$ According to the proposal, Czechoslovakia was authorized (autorisé) to displace maximally 200 thousand persons of Hungarian origin from its territory, according to the principle of the agreement from 27 February 1946.

The most intensive fights about the character of the measures confirmed in the Peace Treaty and thus also about the displacement of 200 thousand of Hungarians from Czechoslovakia took place in the Political and Territorial Commission for Hungary. The Commission was presided by Sinisha Stankovich from Yugoslavia; his deputy was Alfred T. Stirling from Australia. ČSR was strongly represented in that Commission that was of the most importance to it. The Commission reporter was M. Vojna, representative of Ukraine. It must be mentioned that the activities of the Commission had recommending character, similarly to the conclusions of the Paris Conference from 1946 in general. The decisive role in final redaction of the Peace Treaties was played by the Council of Foreign Ministers, consisting of representatives of the Powers. ${ }^{88}$

The talks of the Hungarian Commission discussed, from the perspective of the CzechoslovakHungarian relation, particularly the Czechoslovak amendments on modification of the preamble, on the issue of revisionism, invalidation of the Vienna Arbitration Award, and proposal for rectification of the border (bridgehead area of Bratislava). But the problem of transfer of the Hungarians was ranked first, also from the perspective of the Czechoslovak

85 The procedure of the Peace Conference, including the talks during preparation of the Peace Treaty, is described in more detail by KUKLÍK, 204-220.

86 Paris Peace Conference 1946. Fourth plenary session held on 1 August 1946, 4 P.M, online: http://images. library.wisc.edu/FRUS/EFacs/1946v03/reference/frus.frus1946v03.i0015.pdf, 68-80.

87 AMZV, f. Paris Conference 1946, card file 3. Amendement présenté par la délégation de Tchécoslovaquie Projet de Traité de Paix avec la Hongrie (article 4, paragraphe 3); Russian version in: AMZV, f. Paris Conference 1946, card file 4.

88 Archiv Národního muzea (Archive of the National Museum in Prague, hereinafter referred only as ANM), f. Fedor Hodža, card file 3. Guide de la Conférence de Paris. Édition revisée le 22 aout 1946. Paris: Palais du Luxembourg, 29. Julliet 1946, 51-52. 


\begin{tabular}{c|cr|c}
\hline 84 & $\begin{array}{c}\text { ARTICLES } \\
\text { Štefan ŠUTAJ }\end{array}$ & $\begin{array}{r}\text { Transfer of Hungarians from Slovakia in Gzechoslovak } \\
\text { Politics hefore Paris Peace Conference } 1946\end{array}$ & \\
\hline
\end{tabular}

diplomacy.

The Czechoslovak representatives tried to point out that the Hungarians had been the first satellite of Germany, they had been the most loyal ally of Hitler and stayed with him till the end. V. Clementis presented the Czechoslovak requirement as service to the future of the Hungarian nation. ${ }^{89}$ The Czechoslovak substantiation was directed to support the transfer of 200 thousand Hungarians, trying also to achieve that the transfer issue was dealt with separately and not connected with other issues submitted, as had suggested the "western" delegations. In spite of that, in relation to national environment, V. Clementis warned K. Gottwald and V. Široký in his letters from August and September 1946 that as for unilateral transfer, the optimism of the Czechoslovak press was misplaced as the reality was different. ${ }^{90}$

The effort of the Czechoslovak delegation at the Paris Peace Conference to achieve unilateral displacement of the Hungarians from the ČSR did not find support among the Powers. The result consisted in the "escapist" formulation of Article 5 of the Peace Treaty with Hungary, according to which: „1. Hungary will enter negotiations with Czechoslovakia to solve the issue of inhabitants of Hungarian ethnic origin residing in the Czechoslovakia, who were not settled in Hungary in the spirit of the Agreement from February 27, 1946 of population exchange." If an agreement was not achieved within six months from the day on which this Treaty becomes effective, the ČSR had the right to turn to the Powers. ${ }^{91}$

It can be stated that similarly to the Hungarian side, the Czechoslovak side subsequently claimed fulfilment of Article 5 of the Peace Treaty; only that both sides emphasized different aspects of the article, explaining it from the perspective of their individual interests. Also the draft of the letter prepared by the head of Legal Department of MZV, Zdeněk Procházka, for V. Clementis, emphasized the issue of Article five. Procházka pointed out that "J. Gyöngyösi declared to me openly at the time of the Peace Conference that Hungary was not prepared yet to receive its compatriots from Czechoslovakia." "T2 The letter also states: "I would like to remember that the need of final solution of persons of Hungarian nationality residing in Czechoslovakia was recognized also by the Allied Powers. Article 5 of the Peace Treaty with Hungary specifies verbatim that Hungary will enter negotiations with Czechoslovakia to solve the issue of inhabitants of Hungarian ethnic origin residing in the Czechoslovakia, who were not settled in Hungary in the spirit of the Agreement from 27 February 1946 of population exchange...." ${ }^{193}$ For the Hungarians, the Article constituted the base for effort to protect minority rights of the Hungarians in Czechoslovakia.

The Paris Peace Conference did not satisfy the exaggerated claims of Hungary and Czechoslovakia in relation to their respective neighbour, but it certainly moderated them. Gradually, after the end of the Peace Conference, they had to find way to a joint negotiating

89 Les Archives diplomatiques du ministère des Affaires étrangères, Paris (The Diplomatic Archives of the Ministry of Foreign Affairs, in Paris, hereinafter referred only as AD), f. Y internationale 1944-1948, cotes Y-52-6-SD-11, boîte 262. Commission politique et territoriale pour Hongrie. Réunion 24. Août 1946. See: ROMSICS, 271.

90 NA, f. 100/24, vol. 91, etc. 1089. Letter of V. Clementis to K. Gottwald from 23 August 1946 and letter of V. Clementis to V. Široký from 24 September 1946.

91 AMZV, f. PO, card file 120. Report of Z. Procházka for representative offices from 12 June 1946.

92 Ibidem.

93 Ibidem. 
table where they were pressed by the above stated clause of point five of the Peace Treaty.

\begin{abstract}
The article deals with the activities of the Czechoslovak diplomacy directed at the effort of Czechoslovakia for unilateral displacement of 200 thousand inhabitants of Hungarian nationality from Czechoslovakia to Hungary. It discusses in detail the activities related to ratification of the Armistice Agreement with Hungary, the talks of the Potsdam Conference and the diplomatic activities before the upcoming Peace Conference in Paris in 1946 in relation to the Soviet Union and to the western allies.
\end{abstract}

\title{
Keywords
}

transfer of Hungarians from Czechoslovakia, Paris Conference 1946

\section{References}

Archiv Ministerstva zahraničních věcí (AMZV)

Archive of the Foreign Ministry, Prague

f. London Archive - secret, f. General secretariat of Jan Masaryk and Vladimír Clementis (GS-A), f. Legal Department (PO), f. Paris Conference 1946

Archiv Národního muzea (ANM),

Archive of the National Museum in Prague

f. Fedor Hodža

Archiv Ústavu T. G. Masaryka (AÚTGM)

Archive of T. G. Masaryk Institute in Prague

f. Edvard Beneš II,

Les Archives diplomatiques du ministère des Affaires étrangères, Paris (AD),

The Diplomatic Archives of the Ministry of Foreign Affairs in Paris

f. Y internationale 1944-1948

Národní archiv (NA)

National Archive, Prague

f. London Archive, f. 100/24, f. Office of Presidium of the Government (ÚPV),

Slovenský národný archív (SNA)

Slovak National Archive in Bratislava

f. Office of the Presidium of SNR (ÚP SNR),

Paris Peace Conference 1946. Memorandum of Conversation Frederick T. Merrill-Auer of the United States Delegation, 2 August 1946, online: http://images.library.wisc.edu/FRUS/ 


\begin{tabular}{c|cc|c}
\hline 86 & $\begin{array}{c}\text { ARTICLES } \\
\text { Štefan ŠUTAJ }\end{array}$ & $\begin{array}{r}\text { Transfer of Hungarians from Slovakia in Gzechoslovak } \\
\text { Politics hefore Paris Peace Conference 1946 }\end{array}$ & \\
\hline
\end{tabular}

EFacs/1946v03/reference/frus.frus1946v03.i0015.pdf, 81-84.

Paris Peace Conference 1946. Fourth plenary session held on 1 August 1946, 4 P.M, online: http://images.library.wisc.edu/FRUS/EFacs/1946v03/reference/frus.frus1946v03.i0015. pdf, 68-80.

BARNOVSKÝ, Michal: Sovietsky zväz, komunisti a riešenie mad'arskej otázky na Slovensku v rokoch 1945-1950, in: Bolševismus, komunismus a radikální socialismus v Československu. Vol. III, KÁRNÍK, Zdeněk - KOPEČEK, Michal (eds.), Praha 2004, 154-182.

BOBÁK, Ján: Výmena obyvatel'stva medzi Česko-Slovenskom a Mad'arskom (1947-1948), Bratislava 1994.

IRMANOVÁ, Eva: Postavení mad'arské menšiny na Slovensku po roce 1945, in: Československá historická ročenka, Brno 2002, 19-33.

KAPLAN, Karel - ŠPIRITOVÁ, Alexandra (eds.): ČSR a SSSR 1945-1948. Dokumenty mezistátních jednání, Brno-Praha 1997.

KRNO, M. Dalibor: Paríz 1946. Pripravoval sa mier s Mad'arskom, Praha 1947.

KUGLER, József: Lakosságcsere a délkelet-alföldön 1944-1948, Budapest 2000.

KUKLíK, Jan: Britská diplomacie a československé požadavky na mírovou smlouvu s Mad'arskem, in: Mierové zmluvy v kontexte geopolitiky 20. a 21. storočia, KLIMKO, Jozef - MICHÁLEK, Slavomír a kol., Bratislava 2013, 204-219.

KUKLÍK, Jan - NĚMEČEK, Jan. Zpráva britské diplomacie z Prahy v roce 1945, Praha 2010.

LANTAYOVÁ-ČIERNA, Dagmar: Podoby česko-slovensko-mad'arského vztáahu 1938-1949, Bratislava 1992.

LANTAYOVÁ-ČIERNA, Dagmar: Tradícia a dejiny. Vybrané kapitoly zo slovenskomad'arských a slovensko-ruských vztáahov (1934-1949), Bratislava 2009.

MICHÁLEK, Slavomír, Parížska mierová konferencia 1946 a Československo (východiská, postoje, výsledky, in: Mierové zmluvy v kontexte geopolitiky 20. a 21. storočia, KLIMKO, Jozef - MICHÁLEK, Slavomír (eds.), Bratislava 2013, 192-203.

MOLNÁR, Imré - SZARKA, László (eds.): Otthontalan emlékezet, Komárom 2007.

MURAŠKO, Galina Pavlovna: Vostochnaya Evropa v dokumentakh rossiyskikh arkhivov 1944-1953, Moscow/Novosibirsk 1997.

PARÍKOVÁ, Magdaléna: Reemigrácia Slovákov z Mad'arska v rokoch 1946-1948, Bratislava 2001.

PETRUF, Pavel: Československo na mierovej konferencii v Pariži roku 1946, in: Historický časopis, 33, 1985, 1, 67-82.

POPÉLY, Árpád: Plány na vysídlenie mad'arského obyvatel'stva v rámci výmeny obyvatel'stva medzi Československom a Mad'arskom, in: Fórum. Spoločenskovedná revue, Šamorín 2009, 47-67.

POPÉLY, Árpád: Výmena obyvatel'stva medzi Československom a Mad'arskom a menné zoznamy Mad'arov určených na presídlenie, in: Človek a spoločnost', XII, 2009, 1, URL: http://www.saske.sk/cas/zoznam-rocnikov/2009/1/5850/.

ROMSICS, Ignác: A brit külpolitika és a "magyarkérdés”, 1914-1946, in: Helyünk és sorsunk a Duna-medencében, Budapest 2005, 39-131.

ROMSICS, Ignác: Parížska mierová zmluva z roku 1947, Bratislava 2008.

ŠUTAJ, Štefan: Mad'arská menšina na Slovensku v rokoch 1945-1948, Bratislava 1993. 
ŠUTAJ, Štefan: Nútené presídlenie Mad'arov zo Slovenska do Čiech. Deportácie obyvatel'stva mad'arskej národnosti zo Slovenska do Čiech po druhej svetovej vojne, Prešov 2005.

ŠUTAJ, Štefan: Magyarok csehszlovákiaban 1945-1948 között - kisebbségkutatás, Budapest 2008.

ŠUTAJ, Štefan: Czechoslovak Government Politics and the Population Exchange, in: Memories and Reflections of the Dispossed, MOLNÁR, Imre - SZARKA, László (eds.), Komárom 2010, 83-92.

ŠUTAJ, Štefan: Variace stop Trianonu v politické paměti, in: Trianonská smlouva. Devadesát let poté, DEJMEK, Jindřich - LOUŽEK, Marek (eds.), Praha 2010, 69-97.

ŠUTAJ, Štefan: Trianon a szlovákaia történelmi emlékezetben, in: Limes, XXIV, 2011, 1, 71-86.

ŠUTAJ, Štefan: Mad'arská menšina na Slovensku v rokoch 1945-1948, Bratislava 2012.

ŠUTAJ, Štefan: Výmena obyvatel'stva medzi Československom a Mad'arskom a Parížska mierová konferencia, in: Mierové zmluvy v kontexte geopolitiky 20. a 21. storočia, KLIMKO, Jozef - MICHÁLEK, Slavomír (eds.), Bratislava 2013, 220-243.

ŠUTAJ, Štefan: A mad'ar külpolitika lépései a párizsi békekonferencia előtt - a csehszlovák diplomácia szemszögéből, in: A Közép-Európaiság dicsérete és kritikám, FEDINEC, Csilla - ILYÉS, Zoltán - SIMON, Attila - VIZI, Balázs (szerk.), Pozsony 2013, 613-634.

ŠUTAJ, Štefan: Rokovania o mieri s Mad'arskom a ich vplyv na postavenie mad'arskej menšiny na Slovensku, in: Acta Universitatis Carolinae. luridica, 1, 2013, 277-299.

ŠUTAJ, Štefan: Československé a mad'arské diplomatické aktivity pred Parižskou konferenciou 1946 (z pohladu československej politiky a diplomacie), in: Slovensko v labyrinte európskych dejín, MICHÁLEK, Slavomír a kol., Bratislava 2014, 658-684.

VADKERTY, Katalin: A csehszlovák-magyar lakosságcsere hivatalos szlovák értékelése, in: Regio, 4, 1993, 3, 119-139.

VADKERTY, Katalin: A belsö telepítések és a lakosságcsere, Bratislava 1999.

VADKERTY, Katalin: Mad’arská otázka v Československu 1945-1948, Bratislava 2002. 